\title{
Approaches to School Supervision in Indonesian Context
}

\author{
Ahmad \\ Universitas Muhammadiyah Purwokerto \\ Purwokerto, Indonesia
}

\author{
Marah Doly Nasution \\ Universitas Muhammadiyah Sumatra Utara \\ Indonesia
}

\begin{abstract}
The aim of this paper is to explore some approaches of supervision that can be done by the principal of School in Indonesia and hopefully the approach can be applied in their own school. A literature review was used as a methodology in writing this paper.There are three approaches that can be applied by the school principal in Indonesia for their supervision, namely: directive approach, collaborative approach and non directive approach
\end{abstract}

Key words: supervision, principal, approaches

\section{Introduction}

In Inonesia, the principal's role in the school is not simple, a role that has many duties and responsibilities. From some roles, one role is helping the teachers reinforce and enhance teaching practices that will contribute to improve student learning as well as improve their teaching. To ensure teachers are able to play this role, good leadership and supervision is worthy needed. They need support and motivation that is most often affected by the principal at the school. Studies conducted by Foo Say Fooi et al., (2000) involving 279 teachers found that the supervision carried out by the principal was not only might achieve the school goal but might also give an impact to everyone in the organization. That shows teachers satisfaction is high towards certain leadership function. When teachers are satisfied with their job, their moral are high and productivity is optimum in term of physical, emotional, spiritual and intellect

The principal in Indonesia , as leader, is key in creating a school environment in which supervision can thrive. If a principal is able to practice a positive supervision, it will in turn help bring a positive learning climate to the school. Teachers will feel more comfortable and thus have higher responsibility in teaching. Hoy and Forsyth (1986) contend that the purpose of supervision of instruction is not to judge the competencies of teachers, nor is it to control them but rather to work co-operatively with them.

Teachers will normally be satisfied with their job if they have a good relationship with the principal of their school. Principals conducting the supervision should be positive and open minded (Mohd Kassim,1998), it is done with the objective of helping the teachers concerned in accomplishing their teaching task more effective and high quality. It is not an avenue to pinpoint ones mistake and weaknesses (Segiovanni and Starratt, 1979).
In addition to this maintaining effective school supervision, acting as consultants, advisor and coordinator for teaching and learning activities in schools is one of their important job. Glickman (1990), found that educational supervision is a dynamic process in education aiming at improving the quality of teaching and learning. One of the roles that principals need to play is to be able to carry out the best educational leadership

The aim of this paper is to explore some approaches of supervision that can be done by the principal of School in Indonesia and hopefully the approach can be applied in their own school.

\section{Methodology}

A literature review was used as a methodology in writing this paper. Surveys books, scholarly articles, and any other sources relevant to a particular issue, area of research, or theory, and by so doing, provides a description, summary, and critical evaluation of these works in relation to the research problem being investigated. Literature reviews are designed to provide an overview of sources you have explored while researching a particular topic and to demonstrate to your readers how your research fits within a larger field of study

\section{Discussion of Approaches to Supervision}

Supervisorse ${ }^{\text {ee }}$ use of a particular approach may differ from one teacher to another. Glickman and Gordon (2004) argue supervisors consider the teacher"s level of experience in instructional practices and developmental level when selecting a supervision approach. It is also likely that the contexts within which a supervisor works influences his/her approach. Indonesian school policies as mandated by education depatment may also spell out procedures and approaches to be used by supervisors in their schools. 


\section{Directive approach.}

Supervisors who use a directive approach believe that teaching consists of technical skills with known standards and competencies for all teachers to be effective in their instructional practices (Glickman \& Tamashiro, 1980; Glickman, 2002). According to this approach, the roles of the supervisor are to direct, model, and assess competencies. The directive supervisor sets standards for improvement based on the preliminary baseline information from classroom observation, shows teachers how to attain standards, and judges the most effective way to improve instruction.

The directive supervisory approach takes two forms: directive control and directive informational. In both situations, the supervisor and teacher go through the clinical supervisory stages up to the postconference phase where action plans for improvement are to be taken (Neagley and Evan, 1980). Glickman (1990) indicate that in the directive control supervisory approach, the supervisor details what the teacher is to do, and spells out the criteria for improvement. But in the directive informational approach, the supervisor provides alternative suggestions from which the teacher can choose, instead of telling the teacher what actions to take. The supervisor does not directly determine what action a teacher should embark upon. However, the ideas come from the supervisor.

The directive approach in clinical supervision is a reminiscent of the traditional form of supervision. It presumes that the supervisor is more knowledgeable about instructional procedures and strategies than the teacher, and that his/her decisions are more effective that those of teachers in terms of instructional improvement. However, in the directive approach to supervision the supervisor employs the clinical techniques discussed above, especially a vast array of data collecting instruments. In the traditional model of supervision, all teachers are thought to be at the same level at the same time, and are expected to use the same approach to teaching similar contents. The directive approach to clinical supervision does not emphasize fault-finding as practiced by inspectors in traditional supervision.

Researchers suggest the directive approach to supervision should be employed when dealing with new and inexperienced teachers (Olivia,1997). They believe that this approach should be used in an emergency situation in which the teacher is totally inexperienced, or incompetent in the current classroom situation. Similarly, Glickman (1990) believes this approach is useful when the teacher does not have awareness, knowledge, or inclination to act on issues that the supervisor thinks to be of crucial importance to the students. According to Glickman (1990), this approach is employed "to save the students by keeping the teacher from drowning in the sea of ineffective practice" (p. 83). Pajak (2001) also suggests the directive approach should be used on new and inexperienced teachers. He argues a new teacher may have difficulty grappling with a problem presented in a straightforward manner. He, however, cautions that being overly directive can easily encourage dependency in the new teacher toward the supervisor.

\section{Collaborative approach.}

Supervisors who employ this approach believe that teaching is primarily problem-solving, in which two or more people pose a problem, experiment and implement those teaching strategies that are deemed relevant. According to Glickman (1990), the supervisor"s role in this approach is to guide the problem-solving process, be an active member of the interaction and help keep teachers focused on their common problems.

The leader and teacher mutually agree on the structures, processes, and criteria for subsequent instructional improvement. In the collaborative approach to supervision both the supervisor and teacher mutually negotiate the plan of action (Glickman, 1990). Views of both parties are included in the final plan of action for instructional improvement. According to Glickman, both the supervisor and teacher review, revise, reject, propose and counter propose until they both come to a mutual agreement. He posits that each party must accept modifications of ideas, rather than taking a hard stand.

Glickman (1990) contends that the final product of the collaboration is a contract agreed upon by both and carried out as a joint responsibility in the following manner: Presenting: the leader confronts the teacher with his/her perceptions of the instructional area needing improvement; Clarifying: the leader asks for the teacher"s perceptions of the instructional area in question; Listening: the supervisor listens to teachers" perceptions; Problem-solving: both the supervisor and the teacher propose alternate actions for improvement (supervisor does not impose action plans on teacher); Negotiating: the supervisor and teacher discuss the options and alter proposed actions until a joint plan is agreed upon.

The assumption underlying this approach is that both supervisors and teachers perceive each other as valuable partners in the supervisory process. There is, therefore, a sense of trust and respect between the two parties. The supervisee in this approach is likely to not feel threatened in pursuit of his/her instructional 
practices, and will probably welcome the observation processes.

Collaborative supervision is premised in participation. Glickman and Gordon (2004) and Glickman (1990) suggest that this approach is employed when both the supervisor and teacher intensely care about the problem at hand, and will be involved in carrying out a decision to solve the problem. Glickman and colleague also suggest that this approach should be employed when both the supervisor and teacher have approximately the same degree of expertise on an issue to decide on. The more supervisors involve teachers in decisions affecting their instructional practices, the more the latter make an effort to contribute and are willing to implement a plan they have been part of.

\section{Non-directive approach.}

This approach is based on the premise that teachers are capable of analysing and solving their own instructional problems. Glickman (2002) argues that when an individual teacher sees the need for change and takes responsibility for it, instructional improvement is likely to be meaningful. The leader in this approach is only a facilitator who provides direction or little formal structures to the plan. This behaviour of the leader (supervisor), according to Glickman, should not be misconstrued as passive, or allowing complete teacher autonomy. Instead, the supervisor actually uses the behaviour of listening, clarifying, encouraging and presenting to guide the teacher towards self-recovery.

The leader who adopts the non-directive approach may not use the five steps of the standard format of clinical supervision. Glickman indicates that the supervisor may simply observe the teacher without analysing and interpreting, listen without making suggestions, or provide requested materials and resources rather than arrange in-service training. A nondirective approach to supervision is often employed when dealing with experienced teachers (Hoy, 1986). Glickman (1990) suggests that the non-directive approach to supervision should be employed when a teacher or group of teachers possess most of the knowledge and expertise about an issue and the supervisor"s knowledge and expertise is minimal. Glickman and Tamashiro also suggest that a nondirective approach should be employed when a teacher or a group of teachers has full responsibility for carrying out a decision, or care about solving a problem and the supervisor has little involvement.

When a supervisor has little knowledge and expertise about an issue, he/she can still employ the collaborative approach. On such occasions, the supervisor should not lead the discussion, but rather solicit opinions, ask for clarification, reflect on issues being discussed, and present his/her opinions and suggestions

\section{Conclusion}

There are some approaches of supervision that can be done by Indonesian school supervision in order to improve their teachers $t$ to improve student learning as well as improve the teachers teaching namely: directive approach, collaborative approach and non directive approach. In direct approach, the roles of the supervisor are to direct, model, and assess competencies. The leader and teacher mutually agree on the structures, processes, and criteria for subsequent instructional improvement using collaborative approach. And finally, a non-directive approach should be employed when a teacher or a group of teachers has full responsibility for carrying out a decision, or care about solving a problem and the supervisor has little involvement.

\section{References}

Foo Say Fooi \& Tang Keow Ngang, (2000), Kepimpinan pengajaran pengetuan dan kepuasan guru, Jurnal pengurusan dan pepimpinan pendidikan, Institut Aminuddin Baki, 10(3), pp35-48

Glatthorn, A. A. (1998). Part VIII: Theories of supervision: Introduction. In Firth, G. R. \& Pajak, E. F. (Eds.). Handbook of research on school supervision, (pp. 1029-1031). New York, NY: Simon \& Schuster Macmillan.

Glickman, C. D., Gordon, S. P., \& Ross-Gordon, J. M. (2004). Supervision and instructional leadership: A developmental approach (6th ed.). New York: Pearson Education Inc

Glickman, C. D. (1990). Supervision of instruction: A developmental approach (2nd ed.).Boston: Allan and Bacon.

Hoy, W. K. \& Forsyth, P. D. (1986). Effective supervision: Theory into practice. New York: Random House.

Leddick, G. R. (1994). Models of clinical supervision. ERIC Digest; Eric Clearinghouse on Counseling and Student Services Greensboro, NC

Mohd Kassim Jaafar (1998), Penyeliaan pengajaran: Amalan dan fungsinya dari persepsi guru, Unpublished Master of Education Thesis, University Technology Malaysia, Skudai, Johor (Segiovanni and Starratt, 1979).

Miller, R. \& Miller, K. (1987). Clinical supervision: History, practice perspective. NASSP Bulletin, 71 (18), 18-22. doi: 10.1177/019263658707150305 
Neagley, R. L. \& Evans, N. D. (1980). Handbook for effective supervision of instruction $\left(3^{\text {rd }}\right.$ ed.). Englewood Cliffs, New Jersey: Prentice-Hall Inc.

Oliva, P. F. \& Pawlas, (1997). Supervision for today's schools. (5th ed.). New York: Longman. 